\title{
THE INFLUENCE OF SHARIA BANKING CHARACTERISTICS AND MACROECONOMICS FACTORS ON SHARIA BANKING PROFITABILITY: EMPIRICAL STUDIES IN INDONESIA
}

\author{
Azidni Rofiqo ${ }^{1 *}$, Noni Afrianti ${ }^{2}$ \\ *Corresponding author: \\ ${ }^{1}$ Department of Islamic Economics, University of Darussalam Gontor, rofiqozidni@gmail.com \\ ${ }^{2}$ Departement of Islamic Economics, Institut Agama Islam Negeri bengkulu, noniafrianty.na@gmail.com
}

\begin{abstract}
The problem in this research is the unimmunity of teacher performance of SD Negeri in Mejobo District Kudus Regency. The purpose of this study is to analyze and to know the influence of Islamic Leadership on Teacher Performance through Teacher Competence and Quality of Work Life of Elementary School Teachers. The population of this research is all elementary school teachers from 3 villages in Mejobo District Kudus Regency as many as 129 people. This study used 100 teachers as a sample with Purposive Random Sampling. Datas were obtained from questionnaires and interviews. Data analysis using SPSS 16.0 and Eviews 9. The result of this research is Islamic Leadership, Teacher Competence, and Quality of Work Life positively influence to Teacher Performance. Based on data analysis only Quality of Work Life on Teacher Performance which has no significant effect. Teacher competence and Quality of Work Life can not be considered as intervening variable in this research.
\end{abstract}

Keywords: Islamic leadership, quality of work life, teacher competency, and teacher performance.

\section{INTRODUCTION}

Since the first Islamic Bank existed in 1963, Muslim-majority countries began to establish sharia banks, even some non-Muslim countries also set up Islamic banks (Haron: 2004). The main principle of Islamic banks is to emphasize norms for customers and the bank; profit is not in the form of interest, but profit sharing. At the moment, the growth of sharia banking in Indonesia has become an alternative for people to conduct financial transactions. The success of sharia banks was marked by the strength of sharia banks reached the global monetary crisis in 1998 and 2008 (Republika: 2011).

As a financial sector mediation institution, banks have an important role in the economy. Financial mediation in the banking sector is certainly very important for every country including Indonesia. In Indonesia, the banking system used is a dual banking system which operates two types of bank businesses, namely Islamic banks and conventional banks. That way the policies taken by the government through Bank Indonesia are certainly different for the two types of banks. In Islamic banks do not know the interest system, so that profits can be sourced from profit sharing with business actors who use funds from Islamic banks and investments from Islamic banks themselves (Antonio, 2001).

(Levine, 1996) shows that efficiency in the financial sector will affect economic growth. Thus, the better the level of mediation of a bank in the collection and distribution of funds, the economy of a country will certainly develop faster. However, the financial sector is also very sensitive and closely affected by government policies and macro and micro economic 
conditions in the country concerned (Demirguic-Kunt and Huizinga, 1998). One indicator used to measure the level of profitability is ROA. ROA is important for banks because ROA is used to measure the effectiveness of a company in generating profits by utilizing assets it has. ROA is the ratio of earnings after tax to total assets. The greater the ROA, the better the company's performance, because the rate of return (return) is greater.

Banking significantly contributes to all aspects of the economy (Ahmed, 2010). Rashid and Jabeen said that the banks which have high profitability will get the capital well and easily. In addition, a well-functioning banking system plays an important role in resource allocation, economic growth, and financial performance. Likewise, well-performing finances contribute to increase investment and benefit the entire economy of the country.

In principle, Islamic banks should pay attention to profit and loss sharing mechanisms such as mudarabah and musharaka. However, competition with conventional banks has forced sharia banks to apply the majority of fixed return instruments, such as Murabaha and ijara, and reduced musharaka. Deposits and investment are raised on a Mudarabah / Musharakah basis, while current deposits are earned as qard (loan). The funds are utilized for various investments such as murabaha and ijarah; also reduced musharaka and mudarabah (Rashid \& Jabeen, 2016).

Nienhaus in (Haron, 2004) tried to link the profitability of sharia banks with market structure. Based on his simple table equilibrium model, he said that the profit-sharing ratio (percentage of profits was paid by entrepreneurs) of sharia banks was positively related to the conventional lending rates of banks. (Nienhaus, 1983) did not only suggests that sharia banks should apply interest rates as a basis for calculating the profit-sharing ratio but also recommended that the profit-sharing ratio should be equals with the interest rates offered by conventional banks. He also believed that in a long time, interest-based banking will be more successful than sharia banking. Unfortunately, Nienhaus's hypothesis was not supported by empirical evidence.

(Khan, 1983) extended the Nienhaus model and said that the average return of Islamic banks in a long time would be higher than the interest rate. Khan believed that Nienhaus's argument could be applied when profit-sharing products were provided by conventional banks. Interestingly, Khan admitted that the profit-sharing ratio would have a positive relationship with the interest rate. Like the Nienhaus, the Khan framework was not empirically verified. With the adaptive expectation model, (Haron, 2000) verified hypotheses (Nienhaus, 1983) and (Khan, 1983) and found that conventional interest rates had a positive relationship with shariah bank deposits.

In a financial institution, internal factors such as NPF, FDR, CAR, BOPO determine the performance of a financial institution (Tarawneh: 2006) as well as inflation and GDP (Tamimi: 2010).

(Alper \& Anbar: 2011) examined the performance of Islamic banks and the results of his research showed that interest rates in conventional banks had a positive effect on the profit sharing in Islamic banks. In other words, conventional banks are not different from sharia banks. Apparently, the research needs to be re-examined, as some research (Haron: 2004) and (Rashid and Jabeen: 2016) stated that interest rates did not have a significant effect on the profitability of sharia banks. 


\section{LITERATURE REVIEW AND HYPOTHESES}

(Rashid \& Jabeen: 2016) analyzes the determinants of the performance of conventional banks and sharia banks, they measure by CAMEL'S ratio analysis tool. the results of his research indicate that the operational efficiency, deposit, and market concentration significantly influence the performance of sharia banks, GDP and loan interest rate negatively affect the performance of Islamic banks and conventional. (Haron: 2004) analyzes the determinants of profitability of sharia banks, it uses panel data. The results showed that internal factors: liquidity, total expenditure, funds invested in Syariah securities, and the percentage of profit sharing ratio between banks and borrowers positively affect the income of Islamic banks. External factors: interest rate, market share and firm size, positively affect the ROA of sharia banks. While market share and the money supply has no significant effect on ROA. (Hasan \& Bashir: 2002) examine the related determinants of Islamic Bank profit, the data used is in 1994-2001 in Syariah banks around the world. He uses multiple regression analysis tools, his findings reveal that the ratio of capital and lending to high assets positively affect the profitability of Islamic banks. Implicit and explicit taxes have a negative effect on the performance measures of sharia banks. While the macroeconomic positive effect on the performance measure of Islamic banks.

(Hasan \& Bashir: 2005) examines the determinants of the profitability of Islamic banks. Data used are Islamic Bank data in 21 countries including Indonesia.Untuk bank performance measured by profitability with indicator NIM (Non-Interest Margin), ROA, ROE. The independent variables used are bank characteristics, including assets, and other internal factors such as financing, financial structure, macroeconomic conditions of the country concerned with the proportion of GDP. The result of his research shows that for bank characteristic measured by financing and asset have a positive effect on profitability. Macroeconomic as measured by GDP shows a significant positive effect on NIM, but not significant against ROA and ROA. In the financial structure, market concentration significantly affects profitability.

(Bahloul, Mroua \& Naifar: 2016) examines the effect of macroeconomic and conventional stock price variables on the index of Islamic stock price quotes. He measured with a switching markov regression analysis tool. Data used from 2002-2014. The result of the research shows that Islamic stock index that developed and emerging is influenced by conventional stock return and money supply for both low and high volatility regime. However, it failed to explain the dynamics of the Islamic stock index, especially on the high volatility regime. (Wasiuzzaman \& Ayu: 2009) examines the profitability of Islamic banks in Malaysia. The data used is from 2005-2008. It uses multiple linear analysis tools, it incorporates present quality asset, liquidity, operational, capital and firm size factors. While macroeconomics he put the variable inflation and GDP. The results of the research mentioned that the macro economy, liquidity has a positive effect on ROA, while operational and capital have a negative effect on ROA. While the size of the company has no influence.

(Muda, et.al: 2013) compares the determinants of profitability between domestic Islamic banks and Islamic banks abroad, the data used in 2007-2010, the results of his research show that, the profitability of domestic banks is influenced by overhead costs, loans, the growth rate of gross domestic product and the size of banks and GDP per capita also positively affect the ROA. deposits, capital and reserves, inflation and the age of banks have a significant influence 
in determining bank profits in domestic and foreign banks. liquidity and concentration are unable to explain the variability of profitability of domestic and foreign sharia banks. The findings indicate that the profitability of domestic banks is affected by the temporary global financial crisis, the profitability of foreign banks is not affected. (Al-Gazzar, 2014) examines the financial performance of sharia and conventional banks. It uses CAMEL'S analysis. The result of the analysis shows that CAR, liquidity, and GDP have an effect on the profitability of Syariah bank. (Shaikh, 2013) examines the determinants of the development of Islamic banks in Pakistan, he uses multiple regression analysis. Data from 2007-2012. The result of the analysis shows that the net income has a positive effect on the cost and the asset and negatively affect the NPL. Financial ratios have a positive effect on NPLs, net income, net markup revenue and net revenue markup costs. Asset growth has a positive effect on profitability ratios. From the literature review can be obtained the following hypothesis:

Tabel 1. Hypoteses

\begin{tabular}{|l|}
\hline H1 = BOPO negatively affects ROA \\
\hline H2 = CAR has a positive effect on ROA \\
\hline H3 = FDR has a positive effect on ROA \\
\hline H4 = NPF has a positive effect on ROA \\
\hline H5 = GDP positively affects ROA \\
\hline H6 = Inflation growth negatively affects ROA \\
\hline
\end{tabular}

\section{RESEARCH FRAMEWORK}

(Rivai, 2009) explains that in the banking theory concept there are influences of each variable different from each other. CAR in a bank is very good if the value is above $8 \%$, for FDR the higher the value the better if the range is $80 \%$ to $110 \%$. While for BOPO and NPF the effect tends to be negative if it is associated with profitability.

(Setiawan, 2009) that the relationship between profitability and inflation is negative and is very influential on the world of banking. Whereas the research conducted (Naceur, 2005) contradicts the two studies. According to him, inflation does not have a significant influence on the profitability of banks, especially in Tunisia. (Anthanasoglou, Brissinis, et.al 2008), states that GDP per capita does not have a significant effect on the increase in net interest margin if this variable is included in the profitability equation.

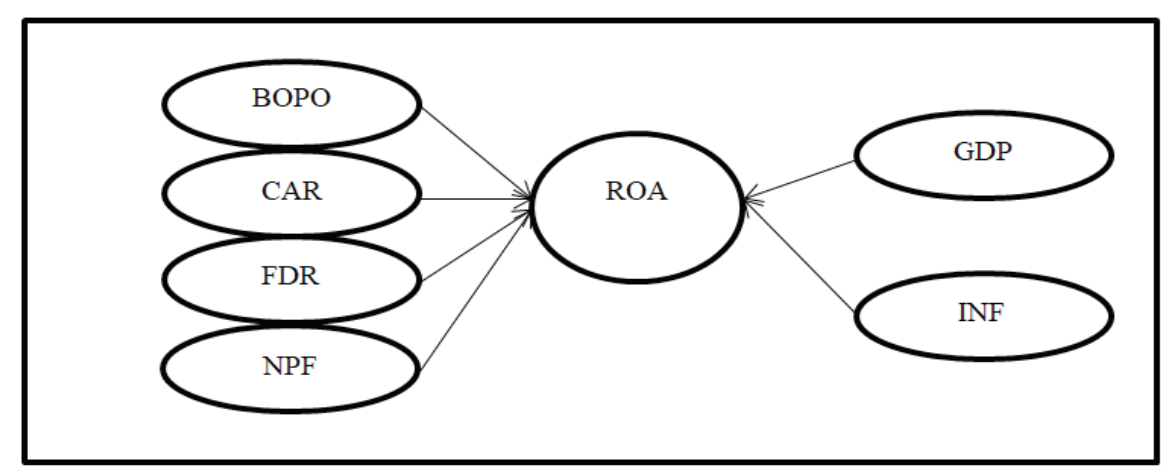

Figure 1: Research Framework 


\section{METHODS}

This research is quantitative research. Quantitative research is a scientific approach to managerial and economic decision making (Kuncoro: 2011). This approach departs from the data, then processed and presented to be valuable information for policyholders.

The variable in this research there are two, that is a dependent and independent variable. The dependent variable is the profitability of sharia banks proxied by return on assets (ROA), while the independent variables are capital adequacy ratio (CAR), operational cost (BOPO), financing to deposit ratio (FDR), non performing finance (NPF), domestic product gross (GDP), and inflation.

Population and sample of this research is sharia commercial bank in Indonesia which amounts to 12 Syariah bank. Types and data sources used are secondary data, in the form of quarterly reports from the Financial Services Authority from 2010 to 2017. Data collection methods used are by indirect observation by visiting the website: bi.go.id, ojk.com.

The analysis technique used in this research is quantitative descriptive, ie data in the form of numbers or measuring units. To analyze the data, the researchers used EVIEWS software assist tool 9. The data analysis method used in this study is a test of classical assumption deviation consisting of normality test, autocorrelation and heteroskedasticity.

Test model in this research by using multiple regression analysis techniques. This analysis technique is used to know the relationship between the dependent variable with the independent variable. The equations are:

$\mathrm{ROA}=\mathrm{a}+\beta_{1} \mathrm{BOPO}_{1}+\beta_{2} \mathrm{CAR}_{2}+\beta_{3} \mathrm{FDR}_{3}+\beta_{4} \mathrm{NPF}_{4}+\beta_{5} \mathrm{PDB}_{5}+\beta_{6} \mathrm{INF}_{6}+\mathrm{E}$.

Analysis of this hypothesis test using partial testing that can be done through observation of significant value at level $\alpha$. This study uses an $\alpha$ level of $5 \%$. If significance $t>0.05$ then $\mathrm{HO}$ is accepted, which means that the independent variable has no significant effect on the dependent variable.

Testing goodness of fit test, this test is done by looking at the value of the coefficient of determination (Adjusted R-Square). When Adjusted R-Square approaches number one, the level of closeness is higher.

\section{RESULTS}

The Results Of The Classical Assumption Test (Normality)
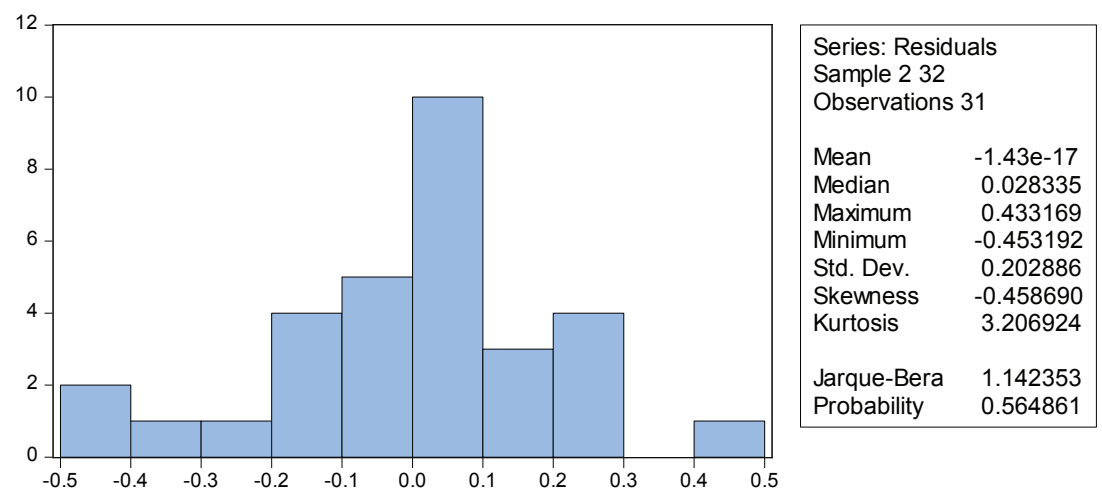

Figure 2: Classical Assumtion Test (Normality Test) 
Looking at the results of the data with tools Eviews 9 can be known probability value JarqueBera $0,564861>0,05$. It can be concluded that the residuals are normally distributed.

The Results Of The Classical Assumption Test (Auto Correlation)

To test whether or not auto correlation researchers used LM Test (Breusch-Godfrey) results:

Table 1: Breusch-Godfrey Serial Correlation LM Test:

\begin{tabular}{llll}
\hline F-statistic & 7.240440 & Prob. F(2,23) & 0.0036 \\
Obs*R-squared & 12.36332 & Prob. Chi-Square(2) & 0.0021 \\
\hline
\end{tabular}

Looking at prob. Chi-Square (2) got value $0.0021<0,05$ hence can be concluded that this model happened auto correlation. To treat auto correlation, researchers used the first different by adding "d" to equition eviews 9 . The results of the auto-correlation test with the first different are as follows:

Table 2: Breusch-Godfrey Serial Correlation LM Test:

\begin{tabular}{llll}
\hline F-statistic & 0.226257 & Prob. F(2,22) & 0.7993 \\
Obs*R-squared & 0.624783 & Prob. Chi-Square(2) & 0.7317 \\
\hline
\end{tabular}

By looking at Chi-Square (2) obtained the value of $0.7317>0,05$ it can be concluded that this model does not have autocorrelation.

The Results Of The Classical Assumption Test (Heteroskedasitas)

The result of heteroscedasticity test using Heteroskedasticity Test: White is as follows:

Table 3: Heteroskedasticity Test: White

\begin{tabular}{llll}
\hline F-statistic & 2.260404 & Prob. F(27,3) & 0.2754 \\
Obs*R-squared & 29.54758 & Prob. Chi-Square(27) & 0.3349 \\
Scaled explained SS & 19.54242 & Prob. Chi-Square(27) & 0.8494 \\
\hline
\end{tabular}

By looking at $\mathrm{Obs} * \mathrm{R}$-squared 29.5475 with Prob. Chi-Square $0.3349>0.05$ then means a homoskedastic model with a 5\% significance level, in other words, the estimated model does not contain heteroscedasticity.

Interpretation Of Coefficient Of Determination, Regression Coefficient And F Test

The coefficient of determination is used to measure how far the ability of the model in explaining the variation of the dependent variable. The results of the data if using tools Eviews 9 as follows: 


\section{Table 4: Intepretation Data}

Dependent Variable: D(ROA)

Method: Least Squares

Date: $02 / 15 / 18$ Time: $13: 46$

Sample (adjusted): 232

Included observations: 31 after adjustments

\begin{tabular}{rrrrr}
\hline Variable & Coefficient & Std. Error & t-Statistic & Prob. \\
\hline C & 0.032526 & 0.051780 & 0.628153 & 0.5358 \\
D(BOPO) & -0.021844 & 0.007568 & -2.886416 & 0.0081 \\
D(CAR) & -0.058596 & 0.052803 & -1.109708 & 0.2781 \\
D(FDR) & 0.020463 & 0.010935 & 1.871308 & 0.0435 \\
D(NPF) & 0.139738 & 0.057153 & 2.444983 & 0.0222 \\
D(PDB) & $-1.77 \mathrm{E}-06$ & $9.10 \mathrm{E}-07$ & -1.941459 & 0.0640 \\
D(INFLASI) & 0.017632 & 0.034878 & 0.505527 & 0.6178 \\
& & & & \\
\hline R-squared & 0.725238 & Mean dependent var & -0.045161 \\
Adjusted R-squared & 0.656548 & S.D. dependent var & 0.387056 \\
S.E. of regression & 0.226834 & Akaike info criterion & 0.066479 \\
Sum squared resid & 1.234883 & Schwarz criterion & 0.390282 \\
Log likelihood & 5.969580 & Hannan-Quinn criter. & 0.172031 \\
F-statistic & 10.55806 & Durbin-Watson stat & 1.635601 \\
Prob(F-statistic) & 0.000009 & & & \\
\hline
\end{tabular}

Based on the results of this study shows that the value of Adjusted R squared coefficient of 0.656548 or $65.6 \%$. This shows that $66 \%$ ROA is influenced by independent variables $=$ BOPO, CAR, FDR, NPF, GDP and Inflation. While the rest of $44.4 \%$ is explained by other variables that are not in this study.

Regression coefficient (T-Test)

This study uses multiple regression analysis. This analysis is used to measure the strength of two or more variables and also shows the direction of the relationship between the dependent variable with the independent variable. Based on the t-test, the decision is as follows:

Tests on BOPO Variables

The first hypothesis states that BOPO has a negative effect on ROA. Based on the results obtained that the significance value $0.0081<0.05$. this means that $\mathrm{H}_{0}$ is rejected and $\mathrm{H}_{1}$ cannot be rejected. This means BOPO has a significant effect on ROA.

Testing of CAR

The second hypothesis states that the CAR has a positive effect on ROA. Based on the results of data calculations can be obtained results of significance value $0.2781>0.05$ which means that $\mathrm{H}_{0}$ cannot be rejected and $\mathrm{H}_{2}$ is rejected, meaning CAR has no significant effect on ROA. 


\section{Testing of FDR}

The third hypothesis states that FDR has a positive effect on ROA. Based on the results of data calculations can be obtained results of significance value $0.0435<0.05$ which means that $\mathrm{H}_{0}$ rejected and $\mathrm{H}_{3}$ is not biased rejected, it means FDR has a significant influence on ROA.

Testing of NPF

The fourth hypothesis states that the NPF has a negative effect on ROA. Based on the results of data calculations can be obtained results of significance value $0.0222<0.05$ which means that $\mathrm{H}_{0}$ is rejected, and $\mathrm{H}_{4}$ is not be rejected, meaning that NPF has a significant influence on ROA. Testing of GDP

The fifth hypothesis states that GDP positively affects ROA. Based on the results of data calculations can be obtained results of significance value $0.6440>0.05$ which means that $\mathrm{H}_{0}$ cannot be rejected, and $\mathrm{H}_{5}$ is rejected, it means GDP has no significant effect on ROA.

Testing Inflation

The sixth hypothesis states that inflation has a negative effect on ROA. Based on the calculation of data can be obtained results of significance value $0.6178>0.05$ which means that $\mathrm{H}_{0}$ cannot be rejected, and $\mathrm{H}_{6}$ rejected, meaning inflation has no significant effect on ROA.

Based on the test results with multiple linear regression method, to test the influence of independent variables to the dependent variable it can be compiled an equation as follows:

$\mathrm{ROA}=0.032526-0.021844 \mathrm{BOPO}-0.058596 \mathrm{CAR}+0.020463 \mathrm{FDR}+0.139738 \mathrm{NPF}-1.77 \mathrm{E}-$ 06 PDB + 0.017632 Inflasi + e

- BOPO regression coefficient is - 0.021844 which means that every $1 \%$ increase of bopo will decrease ROA by $0.021844 \%$ assuming another variable is constant and vice versa.

- The CAR regression coefficient is - 0.058596 which means that any $1 \%$ increase of CAR will reduce ROA by $0.058596 \%$ assuming other variables are constant and vice versa.

- The FDR regression coefficient is 0.020463 which means that every $1 \%$ increase of FDR will increase ROA by $0.020463 \%$ assuming another variable is constant and vice versa.

- NPF regression coefficient is 0.139738 which means that every $1 \%$ increase of NPF will add ROA as much as $0.139738 \%$ assuming another variable is constant and vice versa.

- The regression coefficient of GDP is - 1.77E-06 which means that any $1 \%$ increase in GDP will reduce ROA by $-1.77 \mathrm{E}-06 \%$ assuming other variables are constant and vice versa.

- The regression coefficient of inflation is 0.017632 which means that every $1 \%$ increase of inflation will add ROA as much as $0.017632 \%$ assuming another variable is constant and vice versa.

Regression Coefficient (F-Test)

F-test hypothesis testing is used to see whether at least one independent variable has an influence on the dependent variable. Or it works to see if the variable matches the model. From the F-test results obtained 10.55806 with a significance level of 0.05 . thus the results of the analysis in this study indicate that at least one independent variable affects the ROA, or the model according to the variable. 


\section{DISCUSSION}

The result of the testing of sharia bank characteristic shows that BOPO has a negative effect on bank performance proxy with ROA. This shows that the greater the ratio of total operating costs to operating income will result in lower ROA. While the CAR variable does not affect the ROA this is not in accordance with the research that has been done. Variables FDR and NPF have a positive effect on sharia bank ROA, this is in accordance with previous research.

Test results on the macroeconomic factors proxied by Inflation and GDP indicate that both have no effect on the ROA of sharia banks in Indonesia. Theoretically, the results of research on Syariah banking in Indonesia tend to be more in line with the pure Islamic Economic Theory which explains that in Islamic economy prefers the velocity of money in the real sector so that there is a match between money supply and money demand. In Islam do not know money as a form of investment but only as a means of exchange, so that money must be played for real businesses that bring benefits.

\section{CONCLUSION}

Of the six independent variables that have been tested only BOPO, FDR and NPF variables that significantly affect the ROA. While the CAR, inflation and GDP variables do not significantly influence. The value of $\mathrm{R}^{2}$-Adj 65.6 which means that independent variable outside of this research is still quite a lot, that is around $44,4 \%$ so it can serve as the future agenda related to the profitability of Bank Syariáh.

Along with the alignment of the findings of this study with the predecessor of the model factors that affect the ROA of Islamic banks are still quite consistent to be replicated for the object of research that is equal to different periods or different objects in the same period. It is necessary to add the number of banks examined because, in this research, the 16 banks studied are related to the limitations of existing data access. Furthermore, it is also necessary to add other variables outside of this study that there is a strong possibility to influence ROA such as earnings management, dividend distribution, liquidity, credit type and so on. For this research limited to 6 independent variables. For future research, it can add another macroeconomic variable: the rupiah exchange rate because Islamic banks also carry out real investments related to export imports. The variable that needs further investigation is earnings management, dividend distribution, liquidity and type of financing

\section{REFERENCES}

A., Ahmed, (2010). Global financial crisis: an Islamic finance perspective. International Journal of Islamic and Middle Eastern Finance and Management, 3(4), p. 306-320.

A. Demirguc Kunt, and A. Huizinga (1998). Determinants of Commercial Bank Interest Margins and Profitabilitas: Some International Evidence, World Bank Economic Review $13,379-408$

Al-Gazzar., Manar Mahmood, (2014) The Financial Performance of Islamic vs. Conventional Banks: An Empirical Study on The GCC \& MENA Region, 2014 Faculty of Business, Economics and Political Science's dissertation, The British University in Egypt. 
Anthonasoglou, Brissimis, (2005), Bank spesific industry, and specific makroekonomic determinant of bank profitabilitas. Working paper, bank of greece. No. 25. June.

Antonio., Muhammad Syafi'i (2001). Bank Syariah: Dari Teori ke Praktik. Jakarta: Gema Insani Press.

Bahloul., Slah, Mourad Mroua, Nader Naifar (2011). The impact of macroeconomic and conventional stock market variables on Islamic index returns under regime switching, Borsa-Istanbul Review, 17-1, p. 62-74

D., Alper, Anbar (2011). A. Bank specific and macroeconomic determinants of commercial bank profitability: empirical evidence from Turkey. Business and Economic Research Journal, 2(2), p. 139-152.

F., Khan, M. (1983). Comments on Volker Nienhaus: Profitability of Islamic banks Competing with Interest Banks, Journal of Research in Islamic Economics, Vol. 1, No 2 (Winter), p. 73-78.

H., Tamimi, H.A, (2010). Factors influencing the performance of UAE Islamic and conventional banks. Global Journal of Business Research., 4(2), p. 1-9.

Haron., Sudin, (2004). Determinants Of Islamic Bank Profitability, Global Journal of Finance and Economics. USA, Vol 1, No 1, March

Hasan, Kabir, Abdel Hameed B. Bashir, (2005). Determinants of Islamic Banking Profitability,https://www.researchgate.net/publication/228846468DOI:10.3366/edinburgh/9780748621002.003.0008, ERF Paper

Kuncoro, Mudrajad, \& Suhardjono, (2002). Manajemen Perbankan Teori dan Aplikasinya, Yogyakarta: BPFE.

Levine, Ross. (1996). Financial development and economic growth. Policy Research Paper. The World Bank (forthcoming in Journal of Economic Literature).

M, Tarawneh, (2006). A comparison of financial performance in the banking sector: some evidence from Omani commercial banks. International Research Journal of Finance and Economics, 3(3), p. 101-112.

Muda., Muhamad, Amir Shaharuddin and Abdel Hakim Embaya, (2013). Comparative Analysis of Profitability Determinants of Domestic and Foreign Islamic Banks in Malaysia, International Journal of Economics and Financial Issues, Vol. 3, No. 3, p.559-569.

Neceur, Summy, (2005). The Determinant The Tunisian Banking Industry Profitabilitas. Panel Evidence, ERF Research Follow, Department Of Finance, Universite Libre De Tunis.

Rasyed., Abdul, Sana Jabeen, (2016). Analyzing performance determinants: Conventional versus Islamic Banks in Pakistan, Borsa, Istanbul Review, 16-2, p. 92-107

Rivai and Andria. (2009). Bank and Financial Institution Management. Jakarta: PT. Raja Grafindo Persada. 
Setiawan., Adi, (2009), Analisis Pengaruh Faktor Makroekonomi, Pangsa Pasar dan Karakteristik Bank terhadap Profitabilitas Bank Syariah, Thesis UNDIP.

Shaikh., Salman Ahmed, (2014). Determinants of Islamic Banking Growth in Pakistan, MPRA Paper No. 53798, posted 20. February, 12:33 UTC

Wasiuzzaman., Syaista, Hanimas Ayu, Profitability of Islamic Banks in Malaysia: an Empirical Analysis, Journal Islamic Economic, Banking and Finance, Volume 6, Number-4

https://www.scribd.com/document/157144872/Determinants-Islamic-Banks-Profitibility

http://www.republika.co.id/berita/ekonomi/keuangan/11/09/26/1s3s10-perbankan-syariahtahan-banting-hadapi-krisis-global 